\title{
Academic medicine in Pavia
}

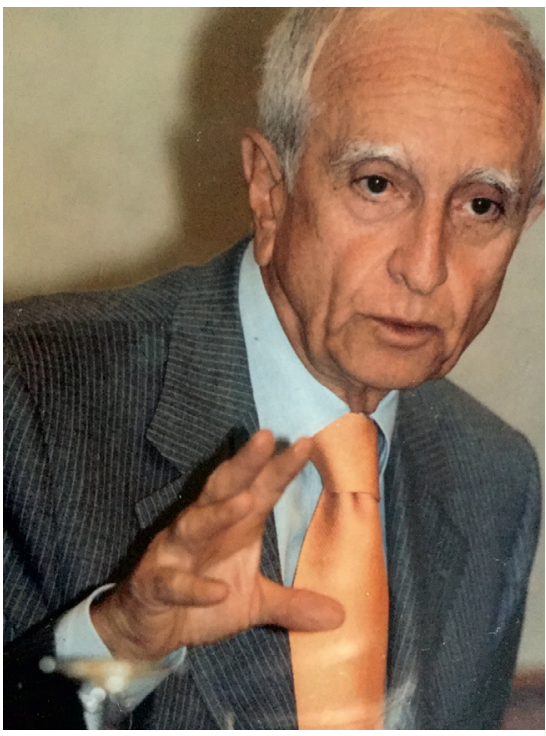

Figure 1. Portrait of the author, source: author's archival materials

\section{The history of Pavia}

Pavia is a city of 73000 inhabitants, located in Lombardy, 34 kilometres south of Milano, on the left bank of the Ticino river; originating from lake Maggiore, the Ticino then flows into the river Po a few kilometres downstream from Pavia. The city was an important stop on the Via Francigena which, originated in northwestern Europe, took pilgrims firstly to Rome and subsequently to southern Italy where they then embarked to reach the Holy Land.

The Ticino was probably the choice of the first settlements by Ligurian and Celtic tribes from transpadan Gaul. It became a Roman municipality in $89 \mathrm{BC}$ and was endowed with the name of "Ticinum". The sewage system and the street organization on two perpendicular axes (the Cardo and the Decumanus) are features present in the map of today's Pavia.- In the fourth century, Pavia was sacked twice, by Attila in 452 and in 476, by a Roman general of barbaric origins, namely Odoacre, whose rebellion against Rome deposed Romolo Augustolo and decreed the end of the Western Roman Empire.

Odoacre was succeeded by Theodoric the Great King of the Goths, who in turn was recognized by the Eastern Empire as King of Italy. In 572 Pavia was conquered by the Lombards and became the effective capital and one of the most important cities of the kingdom with the name of Papia. The adhesion of Lombard sovereignty to Christianity gave rise to intense development of ecclesiastical construction, with the creation both of churches (frequently the seat of royal burials) and of monasteries whose wealth enabled immense development in agriculture and commerce. The substantial economic growth of Pavia, the eminence gained by Pavia on account of its royal seat, the achieved independence of its episcopal see from that of Milano, fuelled the rivalry between the two Lombard cities, both destined to explode in bloody disputes.

When Charles King of the Franks, succeeded in Pepin "the short", repudiated Ermengarda daughter of the Longobard King Desiderio, the Franco-Lombard relations began and rapidly deteriorated. In addition, the highly Francophile and anti-Lombard Pope Adrian, for the refusal of Desiderio to return the invaded territories to the Papal state, asked the French for help on account of Desiderio's refusal to return the invaded territories to Papal State. In 773 King Charles (later known as Charlemagne, an adjective assigned to him after his death by his biographer) invaded Italy and besieged Pavia, where Desiderio had taken refuge. In June 774 Desiderio surrendered. Charles promptly proclaimed himself as king of the Franks, King of the Lombards and as well as a Roman patrician. In 799 the Pope Leo III placed the imperial crown on his head and oversaw an Empire that went from the Pyrenees to the Danube and from the North Sea to Lazio, an act that for the first time sanctioned the secular authority of the Pope and which would prove to be so relevant in the subsequent centuries.

Throughout the Carolingian period, Pavia remained the capital of Italy and maintained its importance, thus distinguish itself from the other prominent Italian cit- 
ies. As an important hub of commercial traffic, Pavia recognized the ease with which the Ticino and the Po facilitated trader's access to Adriatic sea. Recognition of Pavia's cultural status in 825 led Lotario to found the Schola Papiense, the first embryo of the future University.

The new millennium saw the birth of free municipalities, that were eager to achieve political and administrative autonomy. However, excessive eagerness led to new conflicts. among the municipalities themselves and against whom, the Empire or the Papacy, hindered their independence.

In 1056 the ancient rivalry between Pavia and Milano turned into war, with mixed fortunes, until the arrival of Federico I, known as Barbarossa. Frederick Barbarossa came to Italy for the first time in 1154, to tame the free communes that rebelled against imperial authority. Among these, the most belligerent was Milano that Barbarossa, with Pavia at his side attacked and destroyed in 1162. Federico remained in Pavia for a long time and in 1155 he "domiciled" the Italic royal crown, the so-called "iron crown", in the basilica of San Michele. In recognition of the city's support for the empire, he made many concessions in terms of political, administrative and policy independence over Pavia's then vast surrounding territories. At that time the birth of Oltrepò Pavese is attributed.

Governed by the Visconti in the fourteenth century Milano gradually increased its importance and, after alternating fortunes in which the people of Pavia often managed to defend themselves and to impose heavy defeats on the Milano's troops. Pavia definitively surrendered to Galeazzo Visconti in 1359. The Visconti enriched Pavia from the architectural point of view with the construction of the great Castle with its immense park, and from the cultural perspective with the foundation of the University of Pavia in 1361 and the formation of a very rich library known and admired throughout Europe. In the mid-1400s, with the death of the last Visconti, Pavia passed under the control of the Sforza, new lords of Milano. The early 1500s were tragic for Pavia because the city was sacked twice and in 1524 besieged by Francis I of France. The French king was later defeated in 1525 by the Spaniards of Emperor Charles V in the famous battle of Pavia. In the following years, Pavia endured clashes between the French and the Spanish and suffered severe destruction, looting and human losses. As a result in 1530 , the city had only 5000 inhabitants (compared to the 30,000 Pavia inhabitants who had lived there three centuries earlier).

In the following years, Pavia underwent several fluctuating foreign dominations until in 1706. Thereafter the city remained under Austrian control until 1796 when it was occupied by Napoleon.
The Austrian period generated substantial revival for Pavia, thanks mainly to the enlightened government of the emperor Joseph II and his wife Maria Teresa. Great attention was paid to the teaching and research structures of the University where illustrious teachers, from and known throughout Europe, were enrolled. The yellow color that characterises the still extant university buildings of that time is still called "Maria Theresa yellow".

After the brief Napoleonic adventure, Pavia returned to the Austrians in 1814. In 1819 the Naviglio Pavese was completed, a waterway between Milano and Pavia which further favoured inland navigation, so much so that the first steamers were seen and in 1854 the shipping line was established from Pavia to Venice and Trieste.

After the Second War of Independence (1859) Pavia became definitively part of the Kingdom of Sardinia and therefore of the future Kingdom of Italy, which subsequently became a Republic at the end of the disastrous and terrible Nazi-Fascism experience.

\section{The University of Pavia}

The first sketch of the University of Pavia dates back to the year 825 when Emperor Lotario founded Schola Papiensis, with teaching of law suitable for the training of judges and notaries. The real beginning of the University only took place in 1361, under Galeazzo II Visconti and the empire of Charles IV, with the activation of the teachings of the law (canon and civil), medicine, philosophy and the liberal arts: subsequently, the Pope authorized the teaching of theology. Pavia is ,therefore, the second oldest Italian university after that of Bologna (founded in 1088).

In 1429, the first university college for lay and ecclesiastical students from various European countries was founded by Cardinal Branda Castiglioni.

After an initial fractious period that was not easy, the reputation of the University developed considerably between the 14th and 15th centuries, especially for the teachings of law and philosophy.

The terrible war witnessed upheavals in sieges, destruction and looting of the early sixteenth century, events tragically reduced the Pavia population to a few thousand souls. Furthermore, the ongoing alternation of foreign domination greatly hindered the university's activity. The University experienced a strong revival during eightteen century with the arrival of the Habsburgs and in particular of enlightened sovereigns such as Joseph II and Maria Teresa. They promoted immense development of university structures (still existing today) and strengthened teaching and research activities. Between the eighteenth and nineteenth centuries, Alessandro Volta taught physics, Lorenzo Mascheroni mathematics 


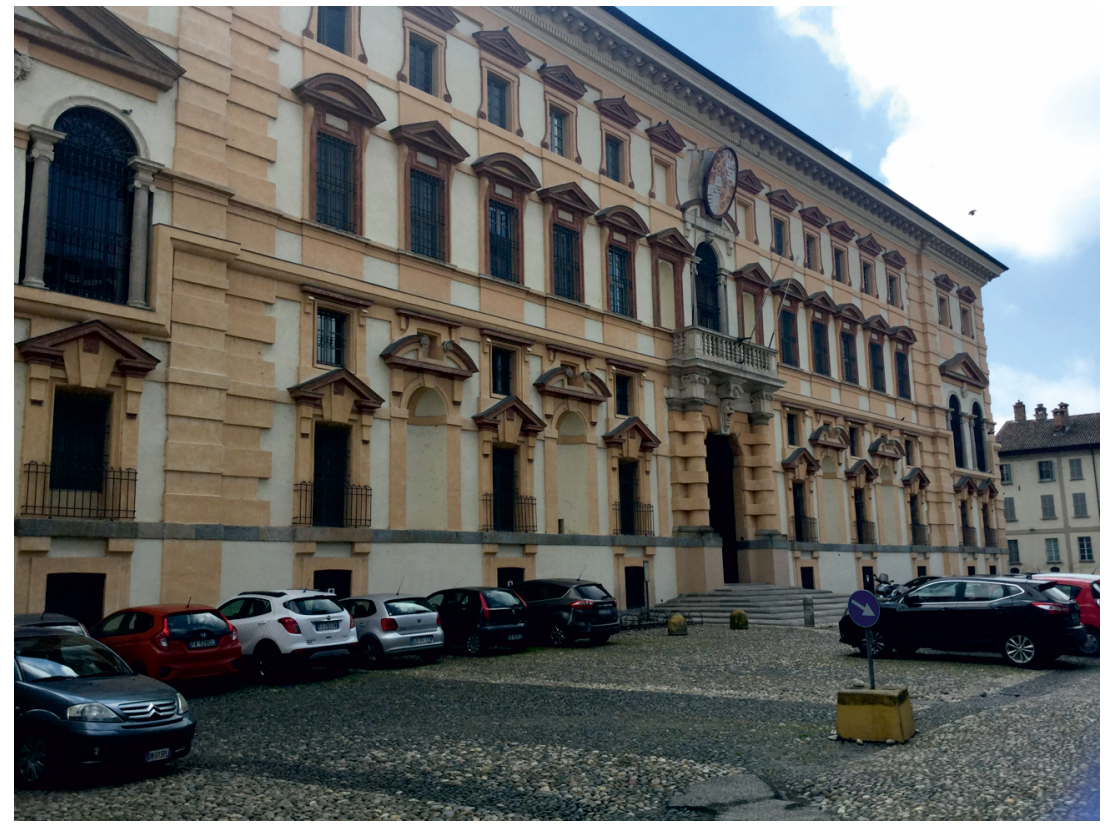

Figure 2. University of Pavia, source: author's archival materials

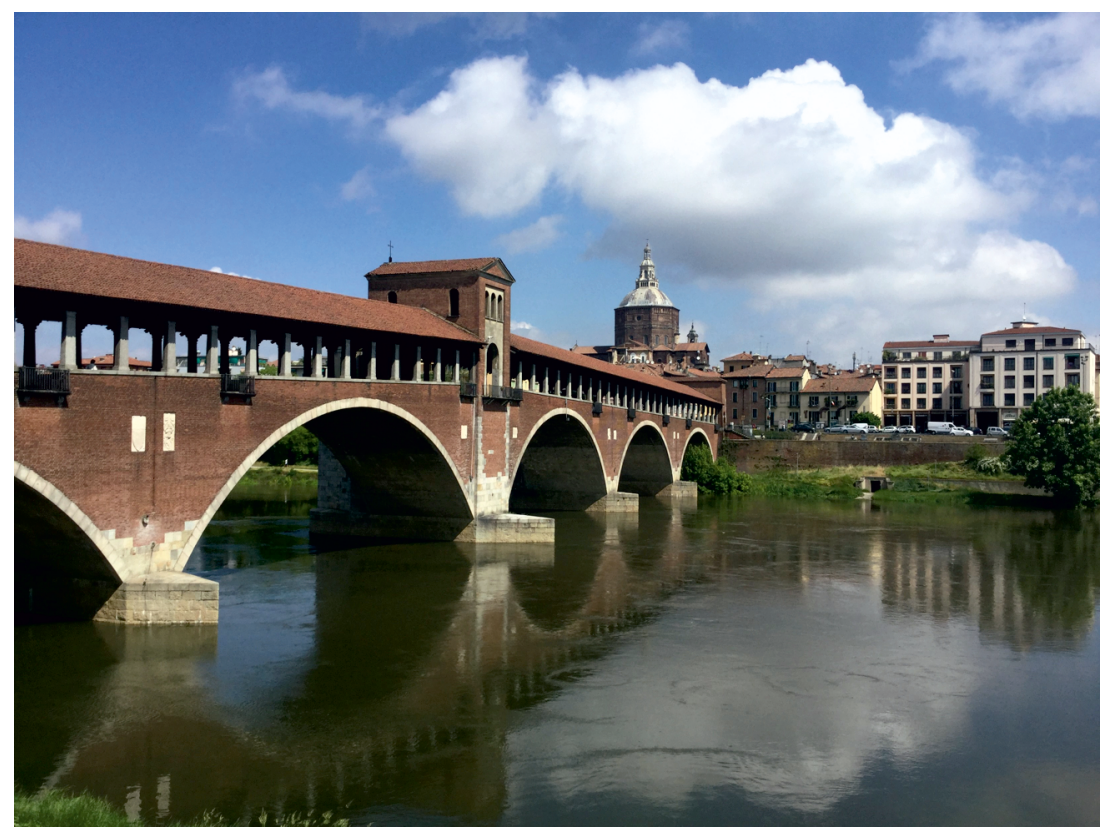

Figure 3. Pavia's Covered Bridge, source: author's archival materials

and Antonio Scarpa and Lazzaro Spallanzani anatomy, Ugo Foscolo and Vincenzo Monti humanities, Carlo Forlanini, the inventor of artificial pneumothorax, medicine. In the early 1900s, the anatomist Camillo Golgi was the first Italian to receive the Nobel Prize.

At the end of the Second World War, the University of Pavia experienced an important structural lopment, thanks above all to the decisive, incisive work of the then current Rector, the historian Plinio Fraccaro.
Currently, the University of Pavia of Pavia is divided into the following Departments (Biology and Biotechnology, Chemistry, Physics, Law, Civil Engineering and Architecture, Industrial and Information Engineering, Mathematics, Internal Medicine and Medical Therapy, Molecular Medicine, Musicology and Cultural Heritage, Public Health, Experimental Medicine and Forensic Medicine, Clinical Surgical Diagnostic and Pediatric Sciences, Economic and Business Sciences, Phar- 
maceutical Sciences, Political and Social Sciences, Nervous System and Behavioral Sciences, Earth and Environmental Sciences, Humanities.

Currently, the University has 23,000 students and employs 1667 teachers and researchers and 886 technical and administrative employees.

In addition, the following Research Centers are active:

- The EUCENTRE Foundation, a body that promotes and develops research in the field of environmental risk reduction, particularly for seismic risk reduction,

- The Institute of Molecular Genetics dedicated to basic research on fundamental biological-molecular processes,

- The Institute of National Nuclear Physics Agency is dedicated to the study of the fundamental constituents of the subject and carries out research in the field of sub-nuclear, nuclear and astro-particle physics,

- The Centre for Health Technologies, a strategic project involving 12 departments, 100 lecturers and $200 \mathrm{PhD}$ dedicated to interdisciplinary scientific research on human health.

- The Park Scientific technician who runs an incubator for biotechnology companies.

\section{University Colleges}

One feature that differentiate Pavia from other Italian universities is the group of 17 colleges that currently welcome both Italian and foreign students and graduates. Said Colleges contribute to various expansions of the entire city's cultural activity, in the form of conferences, courses and seminars, concerts, performances of complex choral music and painting exhibitions. The colleges as a whole host about 2500 students.

The oldest college is the Collegio Castiglioni , which was founded in 1429 by Cardinal Branda Castiglioni to help pupils willing and needy, dedicated to the study of any Faculty of the University of Pavia. It remained open until 1883 and was reopened in 1954 as Collegio Castiglioni Brugnatelli, thus preserving part of the college's original name, to which was added the nomenclature that of the patron Luigi Brugnatelli, who became the owner of the building and left it at the University of Pavia as housing for students. The great merit of having achieved this first secular university female college belongs to Plinio Fraccaro Rector of the University at that time, who was able to break the rigid pattern of time that did not look forward to a lay female college.

The Collegio Ghislieri was founded in 1567 by Pope Pius $\mathrm{V}$ to promote young and deserving people, to obviate poor economic conditions and to promote progress in professional skills in concert with an ethical and religious education. The college was endowed with a rich income which allowed it economic autonomy. Housed in a building designed by the architect Pellegrino Tibaldi, was initially reserved exclusively for clergy, but was entirely secular both in the Napoleonic era and subsequently under Austrian rule. Ghislieri is a private college which can be accessed by competition. In 1965 it was enriched with a women's section, which was subsequently transferred to another peripheral structure with the name of Collegio Nuovo.

Commissioned by Carlo Borromeo, and built on a project by the architect Pellegrino Tibaldi, very famous at that time, Collegio Borromeo itself was inaugurated in 1588; said college aimed to host promising merit worthy young people who were in difficult economic conditions. He was awarded a substantial income from the suppression of two monasteries. The Borromeo is a private college which, from its origins until today, is placed under the patronage of the Borromeo family. Since 2009, a women's section has also been opened adjacent to the original building.

The Collegio Fratelli Cairoli derives from the Germanic-Hungarian College which was built in the second half of the XVIII century under the auspices of the Austrian Emperor Joseph II, with the aim first of preventing the young people of the Empire, to follow theological studies, were forced to reach Rome and then to transfer to Pavia the students already hosted in the existing Germanic Hungarian college in Rome. A fourteenth-century palace was chosen, which was already the seat of the Convent of San Francesco. The restoration of the building was directed by a still young Leopold Pollack. Inaugurated in 1783, the College enjoyed a large patrimonial base that was seized by the French after the occupation by Napoleon. The College was closed in 1798 and transformed into a barracks and remained thus for decades. At the end of the Second World War, Rector Plinio Fraccaro extraordinary commitment enabled him to convince the State Property Office to transfer the ownership of the College to the University of Pavia. After due restoration the College was again reopened, this time as a university college, with the risorgimental name of the Fratelli Cairoli. In 2019, Cairoli College became the only public university college of Pavia to be awarded the status of "Collegio di Merito" . Like the other public colleges in Pavia, it is now managed by the EDISU (an Agency of University of Pavia).

The other University Colleges of Pavia (in alphabetical order):

- Public Colleges (EDISU) : Collegio Gerolamo Cardano (1975), Collegio Giasone del Maino, Collegio Plinio Fraccaro (1963), Collegio Camillo Golgi (1978), Collegio Benvenuto Griziotti (1980), Collegio Lazzaro Spallanzani (1971), Collegio Lorenzo Valla (1985), Collegio Alessandro Volta (2000),

- Private Colleges: Collegio Nuovo (1978) and Collegio Santa Caterina (1971), 
- Colleges managed by religious orders are the Collegio Canossiane Senatore, Collegio Maria Ausiliatrice and Collegio Don Bosco.

\section{"Collegi di Merito"}

The title " Collegio di Merito" imposes annual meritocratic requirements to obtain and maintain this qualification on an annual basis. Various but not exhaustive criteria contribute to the establishment and composition of merit, the average of the marks achieved by the students, the number and level of the accessory courses, the excellence of the cultural events, the international contacts put in place. The title of "Collegio di Merito" is attributed by the Ministry of University and Research.

In Pavia, the "Collegio di Merito" are Collegio Borromeo, Collegio Fratelli Cairoli, Collegio Ghislieri, Collegio Nuovo and Collegio Santa Caterina.

\section{The IUSS}

The University Institute of Higher Studies was born in 1997 , as a consortium formed by the Colleges of Merit of the University of Pavia and EDISU; said consortium with the aim to offer advanced pre-and post-graduate training courses, with additional supplementary courses that are added to normal programs. These are educational, cognitive and cultural teachings of interdisciplinary nature of Human Sciences, Social Sciences, Sciences and Technologies and Biomedical Sciences.

Students accepted after an exam that includes written and oral tests must attend two internal courses per year pertaining to their subject and a third non-inherent course in order to encourage interdisciplinarity.

The intention of the IUSS is to stimulate deserving young people to undertake scientific research and to contribute to the better training of a future leading class.

\section{Museum system in Pavia}

In the rich museum system of the University of Pavia, the brand new natural history museum stands out, and bears the name Kosmos, The original natural history museum was conceived by Maria Teresa of Austria in the mid-1700s and directed for many years by the great Lazzaro Spallanzani was , very recently, moved to a new magnificent location. In addition to containing one of the richest collections in the natural world, it has been reorganized in a completely different way compared to traditional museums. The Museum is inspired by the idea of travel as scientific exploration, by the knowledge of nature and the achievements of biology, through the documentation and findings from the ideas and discoveries of the most famous scientists. Thus, for example, the first five rooms house Spallanzani and his discoveries, from artificial fertilization in the animal to the sixth sense of bats, to the refutation of spontaneous generation and to the possible regeneration of tissues. There is no shortage of excursions on even more modern themes, such as the rooms in which, starting from Darwin and evolutionary theory, we reach today's genetics and the great ecological themes of nature conservation and saving the planet.

In addition to the Kosmos, the Museum of the History of the University, that of Electrical Technology, the respective Museum of Archeology and Mineralogy merit close inspection.

\section{Cardiology in the University of Pavia}

In the history of the University of Pavia, famous names are remembered for having enlarged knowledge in many medical disciplines. Lazzaro Spallanzani (17291799 ) is considered the father of artificial fertilization, Antonio Scarpa (1752-1832) produces such relevant studies on anatomy that his name still identifies some structures of the human body, to Cesare Lombroso (1835-1909), criminologist and precursor of forensic medicine, to Carlo Forlanini (1847-1918), inventor of artificial pneumothorax, a practice that was then essential to save many patients suffering from tuberculosis, to Camillo Golgi (1843-1926) who was awarded the Nobel Prize for Medicine for his studies on the histology of the nervous system, to Casimiro Mondino (1859-1924) who posed the problem of the possible indissolubility of neurology from psychiatry, to the two great scholars of hematology such as Adolfo Ferrata (1880-1946) and Edoardo Storti (1909-2006).

Lazzaro Spallanzani developed a solitary interest in the physiology of the cardio-circulatory system to which, in 1768, he dedicated a book entitled "On the action of the heart in the blood vessels".

The teaching of Cardiology continued to be considered only as a mere part of the large chapter of internal medicine that said the perception of greater or lesser relevance would depend on the internist's main field of interest.

Thus the first major scientific event concerning cardiology in the University of Pavia was the work of a radiologist, Lucio di Guglielmo (1921-2016) who, in 1952 published a study in which for the first time he showed the radiological visualization "in vivo" of coronary arteries of man. The study of coronary anatomy was the starting point for the development of cardiology. Vincenzo Baldrighi and the very young Carlo Montemartini joined in Di Guglielmo. In the following years, 
after a meeting in Switzerland with Andreas Gruntzig, Montemartini was among the first in Italy to promote coronary angioplasty procedure. In 1970 the Policlinico San Matteo in Pavia obtained Cardiology's first building and the University teaching of Cardiology was formalized for students of Medicine and Surgery, with Piero Bobba until 1988. Subsequently, they taught Giuseppe Specchia from 1988 to 1994, Peter J, Schwartz from 1994 to 2014, Stefano De Servi from 2014 to 2916, Gaetano De Ferrari from 2016 to today.

In the years 1970-1988 research continued to be devoted to the study of coronary heart disease with particular attention to myocardial coronary artery vasoconstriction ischemia. A team formed by Luigi Angoli, Ezio Bramucci, Stefano De Servi and Giuseppe Specchia has worked in this field of research for a long time. The ergonovine test was developed for the diagnosis of coronary vasospasm and the perfect equivalence of spontaneous spasm with that induced by the drug was demonstrated. The first demonstration of coronary vasospasm induced by physical exertion and coronary spasm during emotional stress was also published in coronary arteries free from atherosclerosis. In collaboration with the pathologist, Eloisa Arbustini the different histology of coronary plaques was documented on samples taken "in vivo" by atherectomy in patients with stable or unstable angina. In the same period of time Jacek Kubica studied coronary artery pathology different methods such as quantitative coronary angiography and intravascular ultrasound.

Many papers on silent myocardial ischemia have been published and a test has been developed by Colomba Falcone to demonstrate the different pain threshold in patients with silent or expressed by myocardial ischemia pain.

Another group including the one formed by Jorge Salerno and Marcello Chimienti began to develop electrophysiology, first with surface mapping, then with endocavitary mapping and ablation interventions in arrhythmias.

With the arrival of PeterJ Schwartz, the research moved towards two important strands: the study of ionic channel diseases and genetic correspondences and, together with Maria Teresa La Rovere, the search for prognostic parameters in post-myocardial infarction, with particular attention to the importance of autonomic balance, studied through barorereflex sensitivty where they documented that for the same depressed left ventricular function, vagal activation exercised effective protection with a significant reduction in mortality. Still in the field of ionic channel diseases, Silvia Priori has for years represented an undisputed international authority regarding the study of Brugada's disease.

Eloisa Arbustini who is the head of Genetics Lab acquired international fame with the research of cardiovascular genetics and the studies on rare diseases.

The last 20 years, scientific research in Cardiology has also changed its characteristics in Pavia. Individual studies, carried out by small groups of researchers, generally aimed at solving a single pathophysiologic problem have been progressively reduced. This kind of studies has also become unsustainable in a country where public expenditure for the scientific research has been reduced to about half compared to the European average.

As in the whole world, participation in the large international randomized clinical trials prevailed, trials mainly in the therapeutic field, aimed at producing results that can then be used to support an increasingly mandatory evidence-based medicine.

However, there are still groups of clinical researchers, active and lively for scientific interests and publications, such as that of pulmonary hypertension, directed by Stefano Ghio and the one dedicated to the study of acute coronary syndromes headed by Sergio Leonardi. 